\title{
A Review of the Processes Associated with the Removal of Oil in Water Pollution
}

\author{
Bradley Cerff * $\mathbb{B}$, David Key and Bernard Bladergroen
}

check for updates

Citation: Cerff, B.; Key, D.;

Bladergroen, B. A Review of the

Processes Associated with the

Removal of Oil in Water Pollution.

Sustainability 2021, 13, 12339.

https://doi.org/10.3390/su132212339

Academic Editors: Agostina Chiavola and Elena Cristina Rada

Received: 6 September 2021

Accepted: 20 October 2021

Published: 9 November 2021

Publisher's Note: MDPI stays neutral with regard to jurisdictional claims in published maps and institutional affiliations.

Copyright: (c) 2021 by the authors. Licensee MDPI, Basel, Switzerland. This article is an open access article distributed under the terms and conditions of the Creative Commons Attribution (CC BY) license (https:// creativecommons.org/licenses/by/ $4.0 /)$.
South African Institute for Advanced Materials Chemistry (SAIAMC), University of the Western Cape, Robert Sobukwe Road, Cape Town 7530, South Africa; dkey@uwc.ac.za (D.K.); bbladergroen@uwc.ac.za (B.B.)

* Correspondence: bcerff@uwc.ac.za; Tel.: +27-21-913-4011

\begin{abstract}
Water plays an essential role in production and refining processes. Many industries that use petrochemicals also require water, especially for cleaning purposes. The wastewaters released by these processes are often rich in petroleum pollutants, which requires significant treatment prior to disposal. The presence of petroleum contaminants in rivers and oceans is a significant threat to human health, as well as to many animal species. A current challenge for most industries and conventional effluent treatment plants is compliance with accepted disposal standards for oil-polluted wastewater. Of particular importance is the processing of dispersed oil in water, as well as oil in water emulsion. Conventional oil and water separation methods for processing oil in water contamination have several technology gaps in terms of applicability and efficiency. The removal and effective processing of dispersed oil and emulsions from oily wastewater is a costly and significant problem. The objective of this paper is to provide a review of the principles associated with oil in water emulsion separation, with the aim of providing a more definitive understanding of the terminology, processes, and methodologies, which will assist the development of a more efficient, innovative and environmentally friendly process for the separation of oily wastewater.
\end{abstract}

Keywords: oily wastewater; emulsions; processing; treatment; oil-in-water emulsion; oil-water separation

\section{Introduction}

Due to global population growth and increased industrialization over the past 100 years, clean water has become one of the scarcest natural resources on the planet. Clean water is a necessity for life and a fundamental resource for most organisms.

The petroleum industry is considered a water-intensive sector based on the high volumes of water used and wastewater produced in extraction and refining processes [1]. It is estimated that the refining process generates approximately 1.5 times the volume of wastewater for each barrel of crude oil processed [2]. Oily wastewater, water contaminated with petroleum hydrocarbons, is one of the most common environmental pollutants $[3,4]$. Oil pollution can arise either accidentally or operationally, particularly where oil is produced, processed, stored, transported, or used in industrial processes.

The release of untreated oily wastewater can affect the quality of groundwater, seawater, and drinking water, and causes air pollution with the evaporation of volatile oil components to the atmosphere [4,5]. Even when released at very low concentrations, oil contaminants can have a significant impact on the environment [3,6-8]. In some cases, the problems manifest themselves many years after the initial discharge [3,9].

Wastewater-containing petroleum pollutants are a significant challenge for conventional treatment plants, which often do not adequately remove these pollutants. To limit petroleum product pollution and improve discharge water quality, more efficient wastewater treatment technologies are continually being researched, developed, and implemented [10,11]. Governments, companies, and research groups around the world devote considerable efforts and resources to process and remove oil pollutants from water [1,12-14]. 
Various oily wastewater treatment processes have developed from practices without a clear understanding of the underlying chemical and physical properties of the processing method [15].

According to Ober et al., the environment and various industries and sectors, including tourism, depend on the appropriate quality of water resources and even more so on recycled water $[16,17]$. Within this context, the processing and treatment of oil pollutants in water is of crucial importance.

This paper describes the fundamental principles and processes associated with the removal of oil pollution from water. The subsequent sections, Sections 3 and 4, review common industry oil in water processing techniques and the mechanisms associated with oil in water emulsion separation processes, respectively. Section 5 reviews the key properties and parameters of emulsions, while Section 6 describes the emulsion droplet interactions. Section 7 reviews the forces associated with emulsion droplet interactions and Section 8 describes the principles of coagulation and flocculation in the context of oily wastewater treatment. Section 9 evaluates coagulation-flocculation as a fundamental pretreatment process for oily wastewater with specific environmental consideration. Section 10 concludes with a summary of the key points and future opportunities.

\section{Scope and Methodology}

The scope of the work presented includes a review of the fundamental principles, terminology and methods associated with oil in water processing. The manuscript is based on a literature analysis and the review presented here has been necessary to provide an anchor point for terminology and understanding the underlying processes associated with specific separation technologies and the results. The study describes oily water and its emulsions in terms of their main physical properties and droplet interactions and inter-droplet forces that allow for effective separation into oil and water phases.

\section{Oil Contamination in Water}

Oil-contaminated water, often referred to as oily wastewater, can be classified into four categories, namely, free oil, dispersed oil, emulsified oil and dissolved oil [1,18-20]. These categories are defined according to their physical and chemical properties, with a key parameter being the droplet size distribution (DSD) [18,21,22].

The free oil physically separates from the water relatively easily and floats to the surface under calm conditions due to its lower specific gravity compared to water [23]. The oil droplets present in wastewater generally range in size from a few millimeters to large droplets. The oil droplets coalesce relatively easily and float to the top of the water [1].

Dispersed oil is defined as oil in water in the form of droplets, and the DSD is typically in the range of a hundred to few hundreds of microns [23]. Dispersed oils form when mixtures of oil and water move through pumps or pipelines, oily wastewater splashing in vessels, through natural phenomena such as wave action, agitation or processes that will break up free oil and disperse the oil droplets [24-26]. The oil droplets in the dispersion can either coalesce over time to form free oil or can be stabilized, leading to the formation of emulsions.

Oil emulsions that are formed from dispersed oils can be classified as mechanically or chemically stabilized emulsions [27]. Mechanically stabilized emulsions are formed primarily by the surface electrical charge of the oil droplet in the water. Chemically stabilized emulsions form similarly to mechanical emulsions; however, these have additional stability due to interactions of chemical agents at the oil droplet and water interface [28]. Chemical emulsions may contain detergents, soaps, and other additives that prevent coalescence. Depending on the formation conditions and relative proportions of oil and water constituents, multiple emulsions of oil in water $(\mathrm{o} / \mathrm{w})$, water in oil (w/o), as well as complex oil in water in oil (o/w/o) can be formed [29]. In the petroleum, pharmaceutical, and food production industries, the $\mathrm{o} / \mathrm{w}$ and $\mathrm{w} / \mathrm{o}$ simple emulsions are generally more common than the complex emulsions [30]. 
Dissolved oil occurs when oil dissolves in water and there are no oil droplets present. In general, aliphatic hydrocarbons have low solubility in water, however, aromatic hydrocarbons, such as single-ring compounds, e.g., benzene, toluene, ethylbenzene, and xylene, and two-ring naphthalenes, along with phenols and organic acids, form the largest components of dissolved oil [23,31].

\section{Oily Wastewater Processing Techniques}

Various methods are used to process and remove oil pollution from water [24,32-35]. The methods can be categorized as chemical, electrochemical, physical, physiochemical or biological [36-38].

Most industrial oily wastewaters contain oil in water emulsions as the major contaminants [39-41]. Emulsions tend to remain stable as a result of electrostatic repulsion between droplets, preventing them from coalescing into larger droplets, making processing by conventional methods difficult.

The steps in the processes of removing oil from wastewater are firstly methods to remove the free and dispersed oil [42]. Once the free and dispersed oils are removed, the emulsified oil is processed, and the dissolved oil is finally removed from the wastewater. Depending on the characteristics and nature of oily wastewater, treatment methods are classified into primary, secondary, and tertiary processes, which are a function of the specific type of oil pollution in the water. The treatment methods are summarized and presented in Table 1 below.

Table 1. Forms of oil in wastewater and potential processing techniques.

\begin{tabular}{|c|c|c|c|}
\hline Oil in Water Form & Droplet Size & Description & Processing Techniques \\
\hline Free oil & $>100 \mu \mathrm{m}$ & $\begin{array}{l}\text { - Low specific gravity, relatively easy } \\
\text { to process, float, and separate. } \\
\text { - Separate oil droplets of a sufficient } \\
\text { droplet size. } \\
\text { - The buoyancy force causes the oil to } \\
\text { float to the water surface. } \\
\text { The free oil is relatively easily } \\
\text { removed by decanting the floating } \\
\text { surface oil. }\end{array}$ & $\begin{array}{l}\text { - Essentially coalescence and decantation. } \\
\text { Techniques include the following: } \\
\begin{array}{l}\text { API and Parallel Plate } \\
\text { Interceptor gravity } \\
\text { separators [43]; } \\
\quad \text { Long residence time skim tanks; } \\
\quad \text { Induced air flotation-no } \\
\text { chemicals [44]; } \\
\quad \text { Corrugated plate } \\
\text { interceptors [45-47]. }\end{array}\end{array}$ \\
\hline Dispersed oil & $>20 \mu \mathrm{m}$ & $\begin{array}{l}\text { - Oil in the form of small droplets in } \\
\text { water. } \\
\text { Oil droplets are not stable enough to } \\
\text { form an emulsion. } \\
\text { The coalescence and surfacing time } \\
\text { of the free oil depend on the DSD. } \\
\text { Larger droplets with greater buoyancy } \\
\text { rise faster than smaller ones. }\end{array}$ & $\begin{array}{l}\text { - Secondary techniques, designed to } \\
\text { encourage coagulation and coalescence } \\
\text { to form free oil. } \\
\text { Techniques include the following: } \\
\begin{array}{ll}\text { - Hydrocyclone }[48,49] . \\
\circ & \text { Air flotation }[50] . \\
\circ & \text { Centrifugal separation. }\end{array}\end{array}$ \\
\hline \multirow[b]{2}{*}{ Emulsified oil } & $5-20 \mu \mathrm{m}$ & $\begin{array}{l}\text { - Emulsion forms as a result of } \\
\text { mechanical action such as mixing, } \\
\text { valve throttling, shearing, and } \\
\text { wave action. }\end{array}$ & $\begin{array}{l}\text { - Secondary techniques, designed to } \\
\text { destabilize droplets of emulsions and to } \\
\text { form free oil. } \\
\text { - Techniques include the following: }\end{array}$ \\
\hline & $<5 \mu \mathrm{m}$ & $\begin{array}{l}\text { Emulsion forms as a result of } \\
\text { chemical action such as surfactants. }\end{array}$ & $\begin{array}{l}\text { Coagulation treatment }[51,52] \\
\text { Flocculation; } \\
\text { Air flotation-with optimized } \\
\text { chemicals [20]; } \\
\text { Hydrocyclones [23]; } \\
\text { Centrifuges }[53,54] \text {. }\end{array}$ \\
\hline
\end{tabular}


Table 1. Cont.

\begin{tabular}{|c|c|c|c|}
\hline Oil in Water Form & Droplet Size & Description & Processing Techniques \\
\hline \multirow{6}{*}{ Dissolved oil } & & $\begin{array}{l}\text { - Oils that have solubility in water } \\
\text { where an emulsion is formed as a } \\
\text { result of chemical action such }\end{array}$ & $\begin{array}{l}\text { - Tertiary techniques designed to meet } \\
\text { very high-quality discharge limits. } \\
\text { - Tertiary techniques, }\end{array}$ \\
\hline & & as surfactants. & $\circ \quad$ Biological treatment $[13,23,31]$ \\
\hline & & - It cannot be removed from water by & Filtration with sand; \\
\hline & & physical treatment, and it is & Activated carbon; \\
\hline & & $\begin{array}{l}\text { typically removed by adsorption, } \\
\text { chemical oxidation, and }\end{array}$ & $\begin{array}{l}\text { Membrane methods separation } \\
\text { [29] Reverse osmosis; }\end{array}$ \\
\hline & & biological treatment. & Chemical oxidation. \\
\hline
\end{tabular}

In general, it is understood that the physical characteristics of o/w emulsions vary based on the preparation parameters and formulation $[55,56]$.

\section{Emulsion Properties and Parameters}

Emulsions are defined as liquid-liquid colloidal systems with DSD of less than 20 um [57], where colloidal systems are defined as a multiphase heterogeneous system, in which at least one of the phases exists in the form of droplets or solid particles [24]. Emulsions are referred to as multiphase dispersed systems, consisting of two or more immiscible liquids, with the dispersed phase present in the form of droplets in a continuous phase of a different composition [58]. Emulsification is the process of formation of emulsions.

Emulsions are generally classified based on a number of factors; however, the most commonly used are the mode of dispersion, DSD, and thermodynamic stability [29,59-61]. The DSD of oil droplets is an important parameter of an o/w emulsion, which affects the overall stability, rheology, and appearance of the emulsion $[1,59]$.

Emulsions are described as thermodynamically unstable and kinetically stable [62-64]. The theoretical stability and thermodynamics of an emulsion can be expressed by a derivation of the Gibbs free energy as per Equation (1).

$$
\Delta \mathrm{G}=(\gamma \mathrm{A})-(\mathrm{T} \Delta \mathrm{S}),
$$

where $\gamma=$ interfacial tension, $\mathrm{A}=$ interfacial area, $\mathrm{T}=$ temperature, and $\Delta \mathrm{S}=$ mixing entropy.

The magnitude of $\Delta \mathrm{G}$ gives an indication of the thermodynamic stability of an emulsion. If $\Delta \mathrm{G}$ is greater than zero, then the emulsion is relatively unstable and will result in separation. If $\Delta \mathrm{G}$ is less than zero, then the emulsion is stable and no separation will take place [64].

The kinetic stability is a direct result of the DSD and the presence of an interfacial layer between the water and the oil droplet. When this interfacial film between the droplets thins and ruptures, the process of droplet coalescence occurs [65].

The kinetic stability of an emulsion can be increased with surfactants or emulsifiers, often referred to as stabilizing agents [66]. The addition of stabilizing agents slows phase separation by lowering the interfacial free energy through adsorption and the provision of additional electrostatic or steric stabilization at the interface [56,65,67]. The stabilizers suppress the separation mechanisms in emulsions. These types of stabilized emulsions are referred to as microemulsions [68-71].

Oil in water emulsions can remain stable for substantial lengths of time, which, according to Tansel et al., is a function of the droplet surface charge, specific gravity, surface tension, and solubility characteristics relative to the water phase [55]. Eventually, over time, the emulsion will separate into oil and water [61,72]. These types of simple emulsions are referred to as nanoemulsions $[68,70,73,74]$.

Despite some of the environmental issues associated with oil in water emulsions, many emulsions have special properties that make them very useful in many diverse fields 
such as food technology, pharmaceuticals, agriculture, lubricants, cosmetics, laundry, and cleaning agents [74-76].

Emulsions are distinguished from other types of mixtures by several important distinctive properties; these parameters and properties are discussed in the subsequent sections of this paper [77-81].

\subsection{Rheology}

Rheology is defined as the science of the flow and deformation of materials and is the study of the interaction between shear stress, shear strains, and time [62,82]. The flow properties of emulsions are physical attributes that significantly affect the overall stability of emulsions [83-85].

According to Stokes law, the stability of an emulsion, composed of two immiscible liquids with distinct densities, is influenced by DSD and the viscosity of the emulsion $[63,86]$.

$$
\text { vs }=2 \operatorname{gr} 2(\rho 2-\rho 1) / 9 \eta \text {, }
$$

where vs = settling velocity, $\mathrm{r}=$ radius of the droplet, $\mathrm{g}=$ acceleration due to gravity, $\rho 2=$ density of the sphere, $\rho 1=$ density of continuous phase, and $\eta=$ viscosity of the continuous phase.

From Equation (2), a derivation of Stokes law, if the emulsion droplets are denser than the fluid ( $\rho 2>\rho 1)$, then the settling velocity (vs) will be greater than zero and the droplets will fall to the bottom, resulting in sedimentation. If the droplets are less dense compared to the fluid $(\rho 2<\rho 1)$, then the settling velocity (vs) will be less than zero and the droplets will float to the surface.

For an emulsion, we can assume the droplets are spheres and the settling velocity is an indicator of the rate of separation. According to Equation (2), the settling velocity is inversely related to the viscosity of the water phase. This implies that the rate at which an oil droplet will move through the continuous phase increases as the viscosity decreases. It implies that more viscous emulsions are more stable than less viscous ones. This has been confirmed by a number of authors in industrial and pharmaceutical applications of emulsions [28,30,87].

\subsection{Droplet Size Distribution}

Several factors determine the DSD of an emulsion, including bulk properties of the oil and water, presence of solid material, nature of emulsifying agents, and interfacial tension $[18,56,60,88]$.

DSD in an emulsion determines, to a certain degree, the stability of the emulsion and is an important parameter in considering the most suitable processing technique $[11,89,90]$.

\subsection{Zeta Potential}

The zeta potential ( $\zeta$ potential), also often referred to in the literature as electrokinetic potential, is a physical parameter exhibited by solid-liquid and liquid-liquid colloidal systems and emulsions [91-93]. It is an important parameter that describes the surface properties of the droplet suspended in water and gives an indication of the stability of the emulsion $[81,92,94]$.

The magnitude of the $\zeta$ potential gives an indication of the stability of the emulsion and the sign of the $\zeta$ potential gives an indication of the surface charges of the droplet [81]. It is generally accepted that emulsions with $\zeta$ potential values greater than $\pm 30 \mathrm{mV}$ are indicative of stable emulsions [81].

\section{Emulsion Droplet Interactions}

The basis of demulsification is the premise that droplets need to collide with each other, and following the collision, they aggregate and coalesce to form larger droplets and free oil. Three different transport mechanisms are at play to facilitate potential droplet collision, namely, Brownian diffusion, fluid convection, and interparticle interactions. 
During the separation process, oil-in-water emulsions proceed via several stages before separating into the respective phases. To date, the following mechanisms have been identified and extensively discussed in the literature as key steps in the demulsification process: flocculation, creaming, sedimentation, Ostwald ripening, coalescence, and phase inversion $[29,62]$. The above process is also referred to as instability process whereby emulsions separate into the respective phases $[66,95]$. Figure 1 schematically presents the instability process and mechanisms of the $\mathrm{o} / \mathrm{w}$ emulsion phase separation.

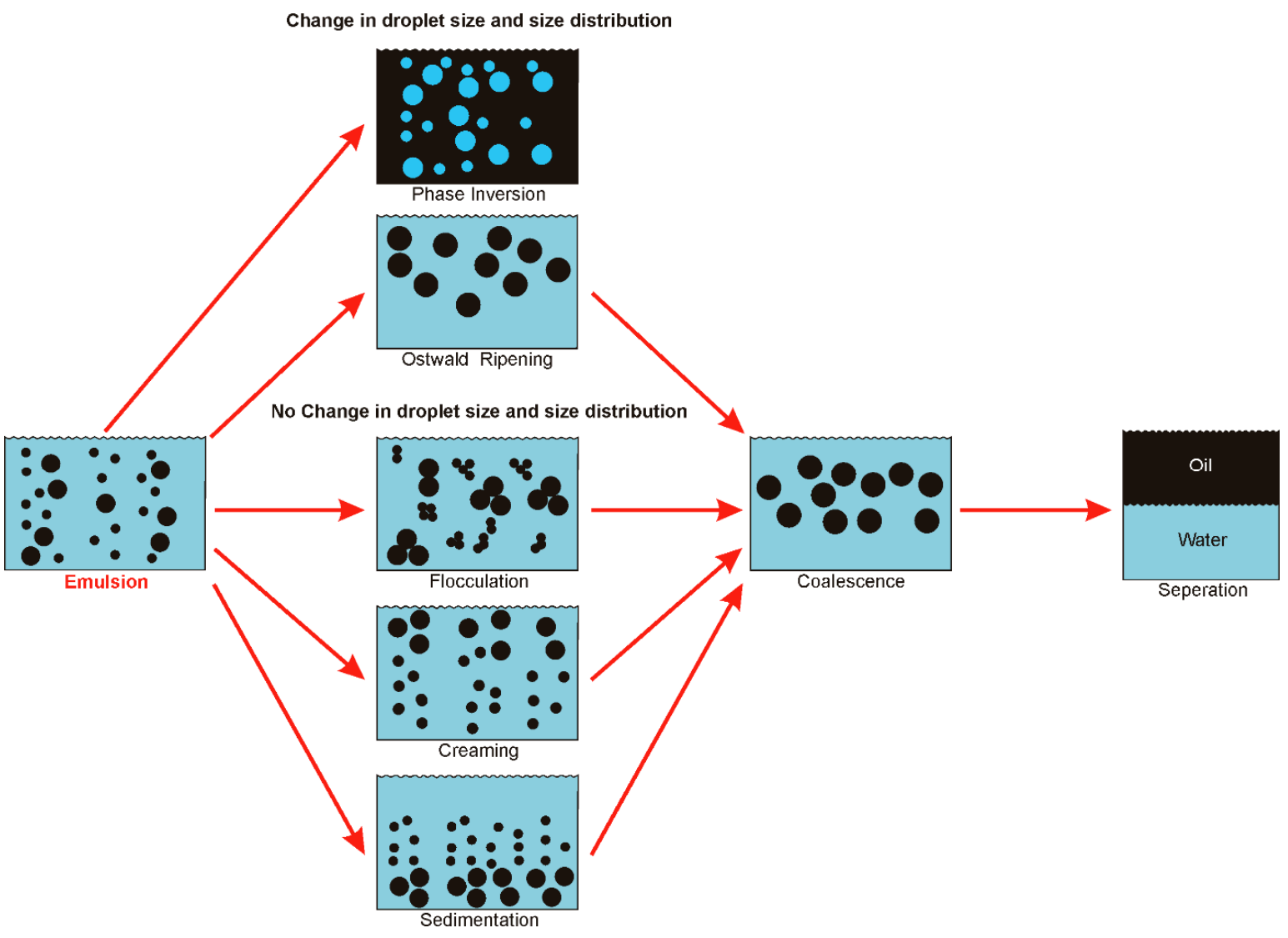

Figure 1. Diagrammatic representation of the oil in water emulsion separation process, Source: Prepared by the authors.

\subsection{Flocculation}

Flocculation is the process where individual droplets in the emulsion aggregate to form flocs [95]. Although the droplets aggregate and even make contact, they do not coalesce and retain their individual droplet characterization. During flocculation, the emulsion structure changes; however, the DSD typically remains unaltered [96].

\subsection{Creaming}

Creaming as a process in an emulsion takes place when the less dense phase migrates to form a layer on top of the denser phase [89]. The creaming phenomenon occurs more readily in $\mathrm{o} / \mathrm{w}$ emulsions, where the droplets move up to the surface because of the low density of the oil droplets. During creaming, the emulsion structure changes; however, the DSD typically remains unchanged [28].

\subsection{Coalescence}

Droplet coalescence is a process in which two droplets merge to form a larger droplet. In order for two oil droplets to coalesce into one larger droplet, the film of liquid trapped between them must drain away [84]. As the drainage proceeds, the film between the 
droplets becomes thin enough for the attractive inter-droplet forces to dominate and to form a thin capillary link between the droplets. This link grows and the droplets coalesce $[56,62]$.

Without the influence of additional emulsifying forces, coalescence can be considered as an irreversible process, which is enhanced by a high rate of flocculation [62,89]. An understanding of the conditions associated with droplet coalescence is important for understanding emulsion separation.

\subsection{Phase Inversion}

Phase inversion occurs when the continuous phase of the emulsion changes to the dispersed phase. This occurs when an o/w emulsion becomes a w/o emulsion. This instability process can also occur when an emulsifier develops solubility in the dispersed phase rather than the continuous phase [69]. Phase inversion can often occur by altering the temperature or increasing the concentration of the electrolyte [62].

\subsection{Ostwald Ripening}

Ostwald ripening of an emulsion is the process in which smaller droplets in an emulsion dissolve into the bulk phase and form on larger existing droplets. It reflects the theory that larger droplets are thermodynamically more stable as the surface area to volume ratio is minimized [65]. The effect is an increase in DSD over time as smaller droplets dissolve and redeposit their material onto larger droplets [62].

Ostwald ripening often occurs in $\mathrm{o} / \mathrm{w}$ emulsions where oil droplets diffuse through the aqueous phase and coalesce with larger droplets [62,65]. With Ostwald ripening, the droplets need not be in close proximity to each other, because the process occurs by transport of dissolved matter through the dispersion medium $[64,65]$.

\subsection{Sedimentation}

Sedimentation is the process that occurs when the denser-dispersed phase forms a layer of droplets at the bottom of the continuous phase. During sedimentation, the emulsion structure changes; however, the DSD typically remains unchanged [24,82].

The phenomena involved in each process highlighted above is relatively complex and requires a detailed understanding of the droplet interactions and associated forces. It should be noted that the processes can take place simultaneously rather than consecutively, which adds to the overall complexity of the processes of demulsification [62].

The destabilizing processes of emulsions have been extensively studied; however, much remains to be investigated relating to the forces acting between droplets and how these forces make destabilization possible.

\section{Forces Related to Droplet Interactions}

Emulsions are stabilized by a balance of competing forces that act to repel or attract the droplets making up the emulsion $[15,97,98]$. The interaction of the forces acting between droplets in the emulsion is an important parameter in determining the properties of the emulsion and the way they interact $[56,83,99]$.

When two oil droplets in an emulsion approach each other, a number of colloidal interactions and forces come into play, including van der Waals, electrostatic, steric hydrophobic, hydrodynamic, and structural components [100,101].

When the attractive forces are weaker than the repelling forces, the droplets tend to remain discrete and dispersed, resulting in the emulsion being stable. It is generally understood that four mechanisms exist which can influence the overall force balance between droplets, including droplet charge neutralization, double layer compression, droplet entrapment, and droplet bridging [102].

The forces interacting on oil droplets in an emulsion are generally categorized according to the Derjaguin, Landau, Vervey, and Overbeek (DLVO) theory [103]. This model was developed in the 1940s and is a simple visualization tool of the balance of forces of a variety of systems in a quantitative manner in terms of the distance between the colloidal 
particles $[103,104]$. The theory, however, has its limitations and the existence of non-DLVO forces has also been proposed and will be discussed in more detail in the subsequent sections $[15,78,100,105]$.

\subsection{DLVO Model}

The DLVO model represents the basis of colloidal particle interactions and their associated aggregation behavior [63]. The DLVO theory for emulsions is based on the following assumptions, which include the following:

- The dispersion is dilute;

- The droplets of the emulsion have the same charge [106,107];

- The charge is distributed uniformly over the droplet surface;

- Only two forces act on the emulsion droplet, these are van der Waals (VdW) and electrostatic forces; and

- The distribution of ions in solution is a function of the electrostatic force and Brownian motion.

The total energy interaction $\left(\mathrm{V}_{\mathrm{T}}\right)$ between two droplets is the resultant force of the sum of the attractive $\left(\mathrm{V}_{\mathbf{V d W}}\right)$ and repulsive $\left(\mathrm{V}_{\text {elec }}\right)$ force, which in simplistic terms can be described by Equation (3):

$$
\mathrm{V}_{\mathrm{T}}=\mathrm{V}_{\mathrm{VdW}}+\mathrm{V}_{\text {elec }}
$$

The total energy interaction $\left(\mathrm{V}_{\mathrm{T}}\right)$ between two oil droplets is obtained by Equation (3) and can be plotted as a function of interparticle distance. A typical interaction of stable dispersions as per the classical DLVO theory with distance is depicted in Figure 2.

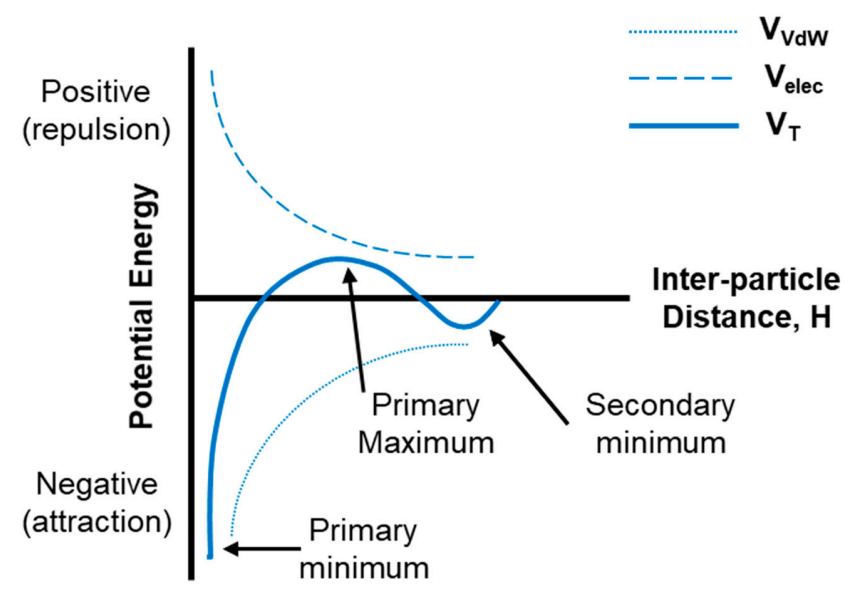

Figure 2. Energy interaction for stable dispersions as per the classical DLVO theory adapted with permission from ref. [108]. 2013 Faraudo et al.

The primary minimum is the lowest-energy state of an emulsion and this is where the droplets are expected to reside in a completely phase separated emulsion [104]. The primary maximum is the energy barrier that must be overcome for coalescence to occur. The secondary minimum is generally seen as the flocculated state, and the droplets will only coalesce when they overcome the primary maximum and reach the primary minimum energy state [103].

When two droplets in an emulsion collide, the following outcomes are possible:

- The droplets collide and do not aggregate but bounce off each other;

- They aggregate and flocculate but do not coalesce; and

- The droplets collide and coalesce. This only happens when the droplets collide with enough energy to surpass the primary maximum state.

DLVO theory suggests that the stability against aggregation in an emulsion is a function of van der Waals attraction and electrostatic repulsion [103]. However, these two 
forces do not represent a full account of all the interactions that may occur in colloidal systems [97]. These include steric repulsion, depletion attraction, hydration and hydrophobic interactions, oscillatory surface forces, and other forces [100]. These forces, often referred to as non-DLVO forces, are discussed in more detail in Section 7.2.

\subsubsection{Van der Waals Interaction}

The van der Waals (VdW) forces are atoms, molecules, and colloidal particles, including emulsion droplets [106]. The origin of this interaction and force originates from electric dipoles in the atoms and molecules [107]. These electric dipoles develop from oscillations in the electron clouds of atoms and molecules. The $\mathrm{VdW}$ interaction is a universal force and present in every system. As mentioned in the previous section, the VdW force between similar particles in a medium is always attractive. The VdW force increases rapidly with decreasing distance between droplets and results in irreversible droplet aggregation in the absence of any other repulsive forces [104].

$\mathrm{VdW}$ forces act over long distances and are relatively strong at short distances. Droplets far away from each other are affected by the VdW force; however, the VdW is relatively weak [109].

\subsubsection{Electrostatic Interaction}

The electric double layer (EDL) model is an important concept in understanding the mechanism of electrostatic force, which is associated with the stabilization of colloids and emulsions $[78,107,110]$. In general, most particles and oil droplets dispersed in water have a negative surface charge and this results in the EDL [107,111]. The process of droplet surface charge and EDL is explained in more detail below.

The EDL is electrically neutral and consists of the following distinct parts around the droplet or particle, which is depicted in Figure 3 and described below:

Surface charge: As a result of the large surface area associated with emulsion droplets, they adsorb ions from the surrounding medium. This imparts an electrostatic charge to the droplets relative to the surrounding medium.

Stern layer: Negatively charged droplets attract positively charged ions that attach firmly to the charged droplet.

Diffuse layer: Outward from the stern layer, there is a high concentration of free counterions. This region is called the diffuse layer, and together, both layers are referred to as the EDL [112].

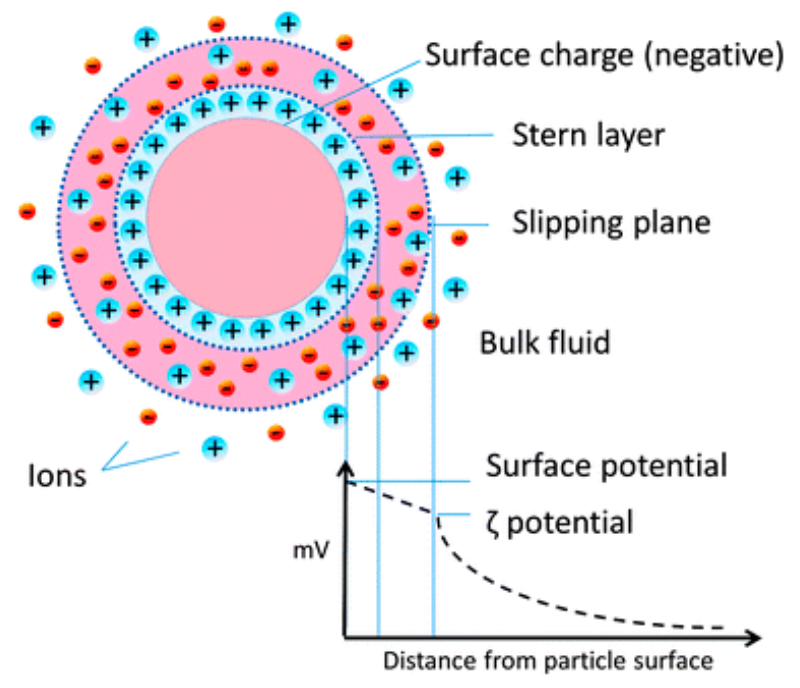

Figure 3. Diagrammatic representation of the electrical double layer, reprinted with permission from ref. [113]. 2014 Marriaga-Cabrales et al. 
Slipping plane: The boundary layer that develops as the colloidal particle moves in the medium and consists of the surrounding liquid close to the particle.

The electrical potential is at its maximum value on the droplet surface. The electrical potential decreases with an increase in distance from the surface of the droplet. The zeta potential is the electric potential at the slipping plane and is an important parameter in the theory and measurement of the interaction of colloidal particles [114].

The approach of two charged oil droplets closer to the thickness of the double layers results in electrostatic interactions and the generation of an electrostatic force between the droplets [78]. It is this electrostatic repulsive force that prevents the droplets from aggregating and consequently contributes to the stability of the emulsion.

\subsection{Non-DLVO Model}

As highlighted in the previous sections, the interaction and behavior of droplets in an emulsion is of significance for a quantitative understanding of the overall stability of the emulsion. For situations where the DLVO theory disagrees with experimental measurements, the model has been extended to include these observed results and referred to as non-DLVO forces $[100,115,116]$.

These additional forces can be much stronger than the DLVO forces at small separation distances and can be repulsive, attractive, and oscillatory. The following interactions, namely, hydrogen bonding and the hydrophobic effect, hydration force, non-charge transfer Lewis acid-base interactions, and steric interactions, are not developed by the traditional DLVO model [79,97,117].

The non-DVLO forces of repulsion which act between droplets in an emulsion include:

- Steric forces, which originate as a result of hydrophilic molecules which become attached to the surface of oil droplets [97];

- Depletion repulsive forces, which are a result of hydrophilic macromolecules dissolved in an aqueous phase [117]; and

- Hydration forces, which are observed at small distances between droplets and result in the surfaces repelling each other [118].

The non-DVLO forces of attraction, which act between droplets in an emulsion include:

- The hydrophobic effect, which describes the attraction between hydrophobic molecules and surfaces that draws them together [79,107]; and

- Depletion attraction forces, which occur in emulsions that have a combination of large and small droplets. According to the literature, the small droplets push the larger droplets toward each when the separation distance between the larger droplets is less than the size of the small droplets $[117,119]$.

\section{Principles of Emulsion Processing}

The technologies and processes associated with breaking and separating emulsions into the phases of oil and water can be induced chemically, electrically, and physically [23,49,120-122]. This process of breaking and separating emulsions is called demulsification.

In order to initiate the separation of the emulsion, droplets need to collide, aggregate, and coalesce to form larger droplets and eventually free oil. Droplets can collide under the influence of three transport mechanisms, namely Brownian diffusion, fluid convection, and droplet interactions [123].

In summary, the process of emulsion separation includes the following steps:

- Droplets need to collide to aggregate, flocculate, and coalesce to form free oil.

- The oil droplets in an emulsion are negatively charged.

- In a pure oil-in-water emulsion, particularly with a small DSD, the electrostatic repulsive force between droplets prevents the droplets from aggregating, flocculating, and coalescing; in other words, their zeta potential is too strong and Brownian diffusion is not sufficient as a transport mechanism to overcome electrostatic repulsion. 
Taking into account the above, one of the key processes always considered in emulsion treatment is the charge neutralization and electrical double layer compression of the individual droplet $[124,125]$. This reduces the repulsive potential of the droplets and allows them to approach each other in closer proximity, potentially forming microflocs. This process of charge neutralization and electrical double layer compression of the individual droplets is known as coagulation $[37,126]$.

The neutralized surface charge and electrical double layer compression directly impacts and lowers the zeta potential of the emulsion, which allows for more favorable droplet interactions and droplet aggregation [127]. Despite coagulation being a simplistic process of droplet charge neutralization, it is often confused with flocculation. The difference between the two processes is further developed and outlined in the following sections.

\subsection{Coagulation}

Coagulation is an essential process in the treatment of industrial wastewater [51,52]. Clarification of water with coagulants was practiced by Egyptians as early as 2000 BC using crushed almonds smeared around a vessel to clarify water [128-130].

Coagulation is one of the most widely applied processes in water treatment to remove suspended particles, decrease turbidity, and remove color [128,131-134].

In practice, coagulation can be achieved by chemical or electrochemical methods, and these are discussed in more detail in the subsequent sections $[135,136]$.

\subsubsection{Chemical Coagulation}

Chemical coagulation is the use of specific chemicals, called coagulants, to drive the coagulation of a colloidal suspension $[135,137]$. The key function of the coagulant is to disrupt the electrostatic forces of repulsion between colloidal particles and results in the formation of microflocs [52,129]. Coagulants are usually metal salts with a high concentration of positive ions. The metal salts increase the concentration of positively charged ions in the diffuse layer around the particle, resulting in the compression of the EDL, reducing the electrostatic repulsive forces between droplets and the formation of microflocs [138]. The microflocs formed during coagulation are usually small, compact, and extremely fragile. The process of coagulation with coagulant is presented in Figure 4.
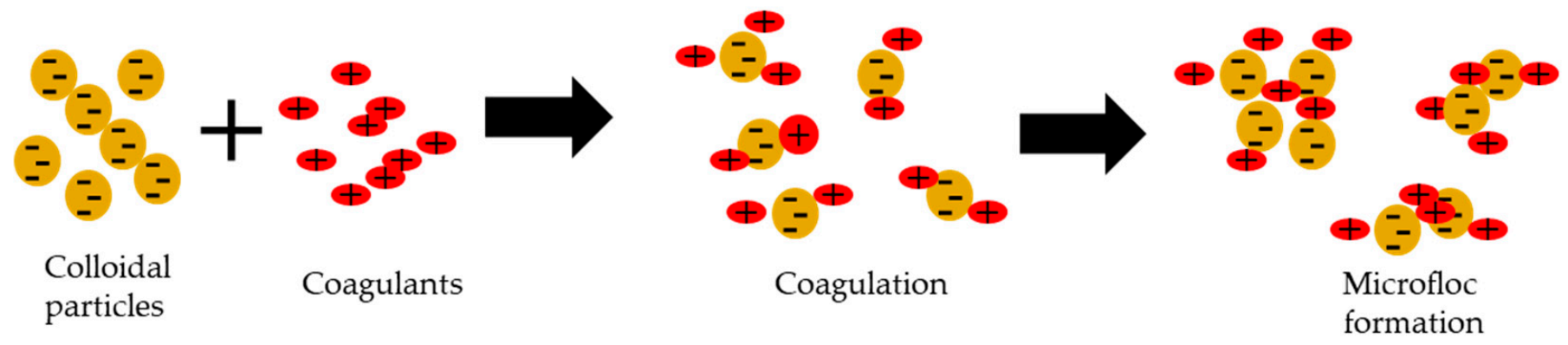

Figure 4. Diagrammatic representation of the coagulation process. Source: Prepared by the authors.

The most widely used commercial coagulants are aluminum sulfate (alum), poly aluminum chloride (PAC), ferric sulfate, and ferric chloride $[38,129,134,137,139,140]$. Alum has been used as a coagulant in water treatment in England and more formally for the treatment of municipal drinking water since 1881 [128].

Aluminum and iron salts dissociate and hydrolyze in their trivalent ionic forms and form positively charged metal complexes, which interact with negatively charged droplets [125].

The selection of the coagulant for the specific emulsion is probably the most important initial process, and this is typically performed through a jar test [141]. The operating parameters which affect the efficiency of the coagulation process include $\mathrm{pH}$, the coagulant type, and the coagulant dosage. 
The extensive use and application of Al-based coagulants in recent years have been a function of cost, overall availability, and efficiency to remove turbidity. In the past few years, the use of ferric-based coagulants has been gaining market share over aluminum coagulants, primarily due to the potential health risks of residual aluminum and the potential improved separation and removal efficiencies of Fe coagulants [142]. The toxicity issues of Al-based coagulants could be attributed to monomeric aluminum ions, which are more available to living organisms than polymeric aluminum [143,144]. The residual aluminum concentration in the treated water was also found to be lower using PACl compared to other aluminum-based coagulants.

Determining the correct concentration of coagulant dose is an important parameter in the overall efficiency of a coagulant. Overdosing with a coagulant can result in charge reversal above the critical coagulant concentration which leads to further electrostatic repulsion resulting in restabilization of oil droplets due to a surplus of positive ions in the aqueous solution. Coagulant overdosing also leads to a considerable increase in the amount of sludge produced, and a lower-than-optimal dose will cause residual metals to remain in the treated water. As highlighted previously, the optimum $\mathrm{pH}$ is also an important parameter during the coagulation process.

\subsubsection{Electrocoagulation}

Electrocoagulation (EC) technology is a wastewater treatment process that applies electrical currents to treat and remove wastewater contaminants $[135,145,146]$. EC is an alternative to classic chemical coagulation, as it reduces the need for chemicals in that the electrodes electrochemically deliver the coagulant into the suspension directly [52,111,147].

EC uses iron or aluminum metal sheet electrodes that are arranged in anodes and cathodes pairs [148]. During the electrolysis, the anodes dissolve in the aqueous phase. The dissolved $\mathrm{Al}$ or Fe ions are hydrolyzed to form polymeric coagulant species $[147,149]$. The overall efficiency of the EC processes is a function of the duration of the electrolysis and concentrations of the targeted contaminants, $\mathrm{pH}$, and conductivity of the aqueous phase.

To date, several studies have investigated the use of EC to improve the separation of emulsions; these have also included the use of EC in combination with other technologies such as centrifugation, filtration, heating, and chemical treatment [150]. In the literature, EC is also often referred to as electro-coalescence [150-152].

In modern water treatment, coagulation is still a fundamental process and often used as a pretreatment process in combination with other processes such as flocculation, filtration, and flotation [114].

\subsection{Flocculation as a Process}

Flocculation is defined as a process that occurs in water treatment when colloidal material particles aggregate with the use of flocculants to form floccules (flocs), which can then be removed from the solution [95,153]. Flocs can be described as loosely held aggregations of small particles.

Flocculants have typically been high molecular weight synthetic polymers; however, in recent years, the trend has been toward natural environmentally friendly and biodegradable flocculants, such as chitosan, tannin, various agricultural gums, and resins [142].

The two basic mechanisms of flocculation are particle bridging and charge patch interactions.

Polymer-induced bridging occurs when droplets are adsorbed onto long-chain polymers with high molecular weight and low charge density [142,154]. Adsorption is considered to be due to hydrogen bonding between active hydroxyl groups in the polymer and hydroxylated sites on particle surfaces [155]. After adsorption and attachment of the droplets, the polymers create bridges from one droplet to the other droplets, forming a three-dimensional matrix, as depicted in Figure 5. 

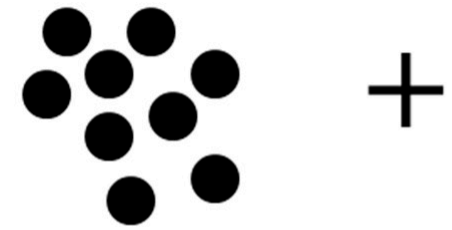

Colloidal particles

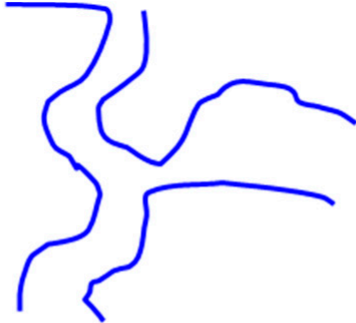

Long chain polymers flocculants

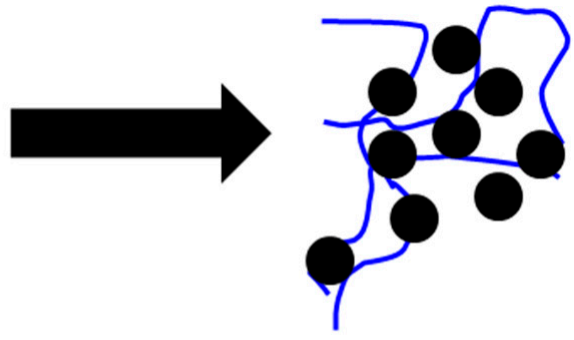

Polymer bridging flocculation

Figure 5. Schematic representation of polymer bridging flocculation. Source: Prepared by the authors.

Charge patch flocculation occurs when positively charged regions of a low-molecularweight polymer adsorb negative colloidal surfaces. It is also called "electrostatic patch" due to the formation of cationic "patches" along the polymer, as depicted in Figure 6.

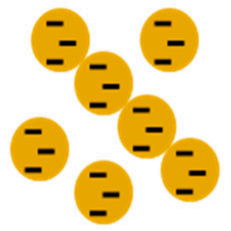

Colloidal particles
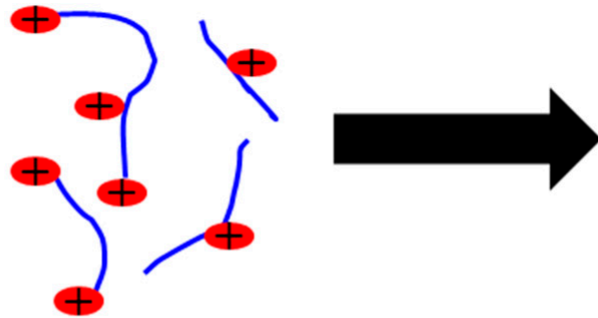

low-molecular-weight

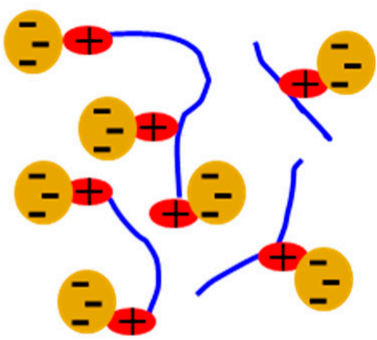

Charge patch flocculation

Figure 6. Schematic representation of charge patch flocculation. Source: Prepared by the authors.

Flocculation is often confused with coagulation, and sometimes the terms are used interchangeably; however, they are completely different phenomena $[95,156]$.

In contrast to the process of coagulation, manipulation of the electric charge of the particle is not the dominant mechanism of flocculation. Flocculation is, in principle, all about collisions between the flocculants and the particles. The flocculation process is generally classified into two types, perikinetic and orthokinetic [153]. Perikinetic flocculation refers to collisions of droplets due to Brownian motion [157-159]. Orthokinetic flocculation is a result of bulk fluid motion, such as stirring, which results in the collisions [157-159].

The process of flocculation and floc formation generally involves the following steps, which occur sequentially:

- Mixing and dispersion of the flocculant;

- Adsorption of the particles onto the flocculant;

- Aggregation of additional particles with the flocculant; and

- The development of larger and stronger flocs.

Flocs are fragile with various internal structures, and in recent years, researchers have focused on the floc breakage and regrowth process to better understand floc characteristics and mechanisms $[160,161]$. The rate of floc formation is a balance between breakage and formation, with the process eventually reaching a steady state either peri- or orthokinetically. The parameters that still need clarification include the number of bonds, location of points of attachment, and internal attractive and repulsive forces within the structure. More efficient flocculants can be developed on the basis of improved understanding of the flocculation mechanism.

Flocculation combined with other treatment processes can be more efficient than flocculation as a process on its own [162]. 


\section{Coagulation-Flocculation Processes as Pretreatments}

Coagulation followed by flocculation is one of the most widely used processes for the removal of suspended solids, colloidal material, organic matter, and for emulsion processing present in industrial wastewater (). The coagulation and flocculation processes are straightforward and efficient methods for wastewater treatment when the fundamentals of the processes are clearly understood.

When flocculation occurs post-coagulation process, the micro flocs created during the coagulation process are further aggregated or brought together to form larger aggregates utilizing controlled levels of flocculants and mixing [162]. Many researchers add coagulants for wastewater treatment even though it might not be necessary. Flocculation as a process can occur after coagulation or without coagulation. For example, flocculants can either be applied on their own or in combination with coagulants, depending on the charge and chemical composition of the solution being separated [142].

When flocculation occurs after a coagulation process, the micro flocs created during the coagulation process are further aggregated to form larger flocs utilizing controlled levels of flocculants and mixing [162]. Polymers are often used as flocculants, which induces the aggregation of particles into larger flakes or flocs [142,154].

Coagulation and flocculation in sequential steps are notably the most common pretreatment process for a number of wastewater treatment applications such as flotation, biological treatment, filtration, and membrane methods.

\section{Conclusions}

As environmental standards become more stringent for the discharge of oily wastewater, processing techniques must be continuously reviewed and evaluated to ensure they meet these standards. It is evident that, based on the scale and complexity of oil pollution in water, there is not one technique that can be considered the silver bullet for treating and processing oily wastewaters and emulsions.

In this review, the principles of emulsion stability related to droplet interactions and the associated inter droplet forces are discussed. It is evident that when the basic principles are clearly understood, efficient and cost-effective methods for wastewater treatment can be developed and implemented. It is on this basis that process such as coagulation and flocculation can be utilized more efficiently. It is evident that coagulation and flocculation will continue to be an essential pretreatment process; however, further research and development activities are required to limit the environmental impacts of existing coagulants and flocculants $[132,163]$. With this understanding, more environmentally friendly and commercially viable natural options derived from plant-based sources may become more mainstream for industrial processes.

It is clear that understanding and integrating the fundamental processes associated with emulsion stability are key components of designing and implementing new and more efficient separation technologies. Therefore, it is on this basis that an understanding of the nature of the emulsion and that of the fundamentals of any treatment process needs to be considered before a process is implemented. Optimization of these factors will significantly increase the efficiency of treatment and reduce the overall processing cost.

Author Contributions: Conceptualization, B.C. and B.B.; writing-original draft preparation, B.C.; writing-review and editing, B.C., B.B. and D.K.; supervision, B.B. and D.K.; funding acquisition, B.B. All authors have read and agreed to the published version of the manuscript.

Funding: This research was funded by the Sasol University Collaboration Program.

Acknowledgments: This work was undertaken as part of a Ph.D. research thesis at the South African Institute of Advanced Materials Chemistry, University of Western Cape, South Africa. The authors express gratitude to all those who helped with the performance of this study.

Conflicts of Interest: The authors declare no conflict of interest. 


\section{References}

1. Jafarinejad, S. Treatment of Oily Wastewater. In Petroleum Waste Treatment and Pollution Control; Butterworth-Heinemann: Oxford, UK, 2017; pp. 185-267, ISBN 9780128092439.

2. Sun, P.; Elgowainy, A.; Wang, M.; Han, J.; Henderson, R.J. Estimation of U.S. refinery water consumption and allocation to refinery products. Fuel 2018, 221, 542-557. [CrossRef]

3. Abdel-Shafy, H.I.; Mansour, M. A review on polycyclic aromatic hydrocarbons: Source, environmental impact, effect on human health and remediation. Egypt. J. Pet. 2016, 25, 107-123. [CrossRef]

4. Council National Research. Oil in the Sea III; National Academies Press: Washington, DC, USA, 2003; ISBN 978-0-309-08438-3.

5. Aljuboury, D.A.D.A.; Palaniandy, P.; Abdul Aziz, H.B.; Feroz, S.A.D.A. Treatment of petroleum wastewater by conventional and new technologies A review. Glob. Nest J. 2017, 19, 439-452. [CrossRef]

6. O'Hara, P.D.; Morandin, L.A. Effects of sheens associated with offshore oil and gas development on the feather microstructure of pelagic seabirds. Mar. Pollut. Bull. 2010, 60, 672-678. [CrossRef] [PubMed]

7. Nordborg, F.M.; Jones, R.J.; Oelgemöller, M.; Negri, A.P. The effects of ultraviolet radiation and climate on oil toxicity to coral reef organisms-A review. Sci. Total Environ. 2020, 720, 137486. [CrossRef] [PubMed]

8. Santo, C.E.; Vilar, V.; Botelho, C.; Bhatnagar, A.; Kumar, E.; Boaventura, R. Optimization of coagulation-flocculation and flotation parameters for the treatment of a petroleum refinery effluent from a Portuguese plant. Chem. Eng. J. 2012, 183, 117-123. [CrossRef]

9. Varjani, S.; Joshi, R.; Srivastava, V.K.; Ngo, H.H.; Guo, W. Treatment of wastewater from petroleum industry: Current practices and perspectives. Environ. Sci. Pollut. Res. 2020, 27, 27172-27180. [CrossRef] [PubMed]

10. Abbassi, B.; Livingstone, T. A Comparative Review and Multi-criteria Analysis of Petroleum Refinery Wastewater Treatment Technologies. Environ. Res. Eng. Manag. 2019, 74, 66-78. [CrossRef]

11. Benyahia, F.; Abdulkarim, M.; Embaby, A. Refinery wastewater treatment: A true technological challenge. In Proceedings of the Seventh Annual UAE University Research Conference, Al-Ain, United Arab Emirates, 22-24 April 2006. [CrossRef]

12. Rowland, G.; Walsh, J. Addressing Gaps in Water Treatment Technology. J. Pet. Technol. 2013, 65, 82-88. [CrossRef]

13. Ishak, S.; Malakahmad, A.; Isa, M.H. Refinery wastewater biological treatment: A short review. J. Sci. Ind. Res. (India) 2012, 71, 251-256.

14. Radelyuk, I.; Tussupova, K.; Zhapargazinova, K.; Yelubay, M.; Persson, M. Pitfalls of Wastewater Treatment in Oil Refinery Enterprises in Kazakhstan-A System Approach. Sustainability 2019, 11, 1618. [CrossRef]

15. Hendricks, D.W. Water Treatment Unit Processes; CRC Press: Boca Raton, FL, USA, 2010; ISBN 9781420061925.

16. Karwot, J.; Ober, J. Safety Management of Water Economy. Case Study of the Water and Sewerage Company. Manag. Syst. Prod. Eng. 2019, 27, 189-196. [CrossRef]

17. Ober, J.; Karwot, J. Tap Water Quality: Seasonal User Surveys in Poland. Energies 2021, 14, 3841. [CrossRef]

18. Cheremisinoff, P.N. Oil/water separation. Met. Finish. 1999, 97, 70. [CrossRef]

19. Alther, G. Cleaning wastewater: Removing oil from water with organoclays. Filtr. Sep. 2008, 45, 22-24. [CrossRef]

20. Saththasivam, J.; Loganathan, K.; Sarp, S. An overview of oil-water separation using gas flotation systems. Chemosphere 2016, 144, 671-680. [CrossRef] [PubMed]

21. El-Naas, M.; Abu-Alhaija, M.; Al-Zuhair, S. Evaluation of a three-step process for the treatment of petroleum refinery wastewater. J. Environ. Chem. Eng. 2014, 2, 56-62. [CrossRef]

22. Welz, M.; Baloyi, N.; Deglon, D. Oil removal from industrial wastewater using flotation in a mechanically agitated flotation cell. Water SA 2010, 33, 453-458. [CrossRef]

23. Li, X.; Liu, J.; Wang, Y.; Xu, H.; Cao, Y.; Deng, X. Separation of Oil from Wastewater by Coal Adsorption-Column Flotation. Sep. Sci. Technol. 2014, 50, 583-591. [CrossRef]

24. Abdulredha, M.M.; Aslina, H.S.; Luqman, C.A. Overview on petroleum emulsions, formation, influence and demulsification treatment techniques. Arab. J. Chem. 2020, 13, 3403-3428. [CrossRef]

25. Delvigne, G.A.L.; Kuiper, J.; Brink, W.J. Droplet Size Distribution of Naturally Dispersed Oil. In Fate and Effects of Oil in Marine Ecosystems; Springer: Berlin/Heidelberg, Germany, 1987; Volume 28, pp. 29-40.

26. Delvigne, G.; Sweeney, C. Natural dispersion of oil. Oil Chem. Pollut. 1988, 4, 281-310. [CrossRef]

27. Loh, A.; Shankar, R.; Ha, S.Y.; An, J.G.; Yim, U.H. Stability of mechanically and chemically dispersed oil: Effect of particle types on oil dispersion. Sci. Total Environ. 2020, 716, 135343. [CrossRef]

28. Nikovska, K. Study of olive oil-in-water emulsions with protein emulsifiers. Emir. J. Food Agric. 2012, 24, 17-24. [CrossRef]

29. Saad, M.A.; Kamil, M.; Abdurahman, N.H.; Yunus, R.M.; Awad, O.I. An Overview of Recent Advances in State-of-the-Art Techniques in the Demulsification of Crude Oil Emulsions. Processes 2019, 7, 470. [CrossRef]

30. Haghighat, A.K.; Olsen, M.G.; Vigil, R.D.; Sarkar, A. Droplet coalescence and phase separation in a topical ointment: Effects of fluid shear and temperature. Int. J. Pharm. 2020, 591, 119872. [CrossRef] [PubMed]

31. Fakhru'L-Razi, A.; Pendashteh, A.; Abdullah, L.C.; Biak, D.R.A.; Madaeni, S.S.; Abidin, Z.Z. Review of technologies for oil and gas produced water treatment. J. Hazard. Mater. 2009, 170, 530-551. [CrossRef]

32. Zhao, C.; Zhou, J.; Yan, Y.; Yang, L.; Xing, G.; Li, H.; Wu, P.; Wang, M.; Zheng, H. Application of coagulation/flocculation in oily wastewater treatment: A review. Sci. Total Environ. 2021, 765, 142795. [CrossRef]

33. Yu, L.; Han, M.; He, F. A review of treating oily wastewater. Arab. J. Chem. 2017, 10, S1913-S1922. [CrossRef] 
34. Khader, E.H.; Mohammed, T.H.J.; Mirghaffari, N. Use of Natural Coagulants for Removal of COD, Oil and Turbidity from Produced Waters in the Petroleum Industry. J. Pet. Environ. Biotechnol. 2018, 9, 1-7. [CrossRef]

35. Rocha e Silva, F.C.P.R.; e Silva, N.M.P.R.; da Silva, I.A.; Brasileiro, P.P.F.; Luna, J.M.; Rufino, R.D.; Santos, V.A.; Sarubbo, L.A. Oil removal efficiency forecast of a Dissolved Air Flotation (DAF) reduced scale prototype using the dimensionless number of Damköhler. J. Water Process. Eng. 2018, 23, 45-49. [CrossRef]

36. Tee, P.F.; Abdullah, M.O.; Tan, I.A.W.; Rashid, N.K.A.; Amin, M.A.M.; Nolasco-Hipolito, C.; Bujang, K. Review on hybrid energy systems for wastewater treatment and bio-energy production. Renew. Sustain. Energy Rev. 2016, 54, 235-246. [CrossRef]

37. Osman, M.; Awaleh, M.O.; Soubaneh, Y.D. Waste Water Treatment in Chemical Industries: The Concept and Current Technologies. J. Waste Water Treat. Anal. 2014, 5, 1-13. [CrossRef]

38. Dhote, J.; Ingole, S.P. Review on Waste Water Treatment Technologies. Int. J. Environ. Res. Technol. 2012, 1, 1-10.

39. Al-Futaisi, A.; Jamrah, A.; Yaghi, B.; Taha, R. Assessment of alternative management techniques of tank bottom petroleum sludge in Oman. J. Hazard. Mater. 2007, 141, 557-564. [CrossRef] [PubMed]

40. Machín-Ramírez, C.; Okoh, A.; Morales, D.; Mayolo-Deloisa, K.; Quintero, R.; Trejo-Hernandez, M.R. Slurry-phase biodegradation of weathered oily sludge waste. Chemosphere 2008, 70, 737-744. [CrossRef] [PubMed]

41. Chen, G.; He, G. Separation of water and oil from water-in-oil emulsion by freeze/thaw method. Sep. Purif. Technol. 2003, 31, 83-89. [CrossRef]

42. Kenawy, F.; Kandil, M. Comparative Evaluation between a Modified CFP Separator and All Other Available Oil-Water Separation Techniques. In Proceedings of the SPE International Conference on Health Safety, and Environment in Oil and Gas Exploration and Production, Caracas, Venezuela, 7-10 June 1998. [CrossRef]

43. Judd, S.; Qiblawey, H.; Al-Marri, M.J.; Clarkin, C.; Watson, S.; Ahmed, A.; Bach, S. The size and performance of offshore produced water oil-removal technologies for reinjection. Sep. Purif. Technol. 2014, 134, 241-246. [CrossRef]

44. Tsuge, H.; Li, P.; Hirofumi, O. Application of Induced Air Flotation on Water Treatment. Asian Pacific Confederation of Chemical Engineering Congress Program and Abstracts, 2004, 1-7. Available online: https://www.jstage.jst.go.jp/article/apcche/2004/0 /2004_0_620/_article/-char/en (accessed on 19 April 2021).

45. Umar, A.A.; Saaid, I.B.M.; Sulaimon, A.A.; Pilus, R.B.M. A review of petroleum emulsions and recent progress on water-in-crude oil emulsions stabilized by natural surfactants and solids. J. Pet. Sci. Eng. 2018, 165, 673-690. [CrossRef]

46. Hirasaki, G.J.; Miller, C.A.; Raney, O.G.; Poindexter, M.K.; Nguyen, D.T.; Hera, J. Separation of Produced Emulsions from Surfactant Enhanced Oil Recovery Processes. Energy Fuels 2011, 25, 555-561. [CrossRef]

47. Stewart, M.; Arnold, K. Produced Water Treating Systems. Emuls. Oil Treat. Equip. 2009, 107-211. [CrossRef]

48. Krebs, T.; Schroen, K.; Boom, R. Separation kinetics of an oil-in-water emulsion under enhanced gravity. Chem. Eng. Sci. 2012, 71, 118-125. [CrossRef]

49. Bai, Z.-S.; Wang, H.-L.; Tu, S.-T. Oil-water separation using hydrocyclones enhanced by air bubbles. Chem. Eng. Res. Des. 2011, 89, 55-59. [CrossRef]

50. Radzuan, M.A.; Belope, M.A.-B.; Thorpe, R. Removal of fine oil droplets from oil-in-water mixtures by dissolved air flotation. Chem. Eng. Res. Des. 2016, 115, 19-33. [CrossRef]

51. Kulkarni, S.J. Coagulation for Wastewater Treatment: A Review on Investigations and Studies, article. Int. J. Sci. Res. Sci. Technol. 2017, 3, 501-505.

52. Ghernaout, D. Advanced oxidation phenomena in electrocoagulation process: A myth or a reality? Desalination Water Treat. 2013, 51, 7536-7554. [CrossRef]

53. Da Rosa, J.J.; Rubio, J. The FF (flocculation-flotation) process. Miner. Eng. 2005, 18, 701-707. [CrossRef]

54. Verma, A.K.; Dash, R.R.; Bhunia, P. A review on chemical coagulation/flocculation technologies for removal of colour from textile wastewaters. J. Environ. Manag. 2012, 93, 154-168. [CrossRef]

55. Tansel, B.; Sevimoglu, O. Coalescence and Size Distribution Characteristics of Oil Droplets Attached on Flocs After Coagulation. Water Air Soil Pollut. 2006, 169, 293-302. [CrossRef]

56. Friberg, S.E. Emulsion Thermodynamics-In from the Cold. Substantia 2018, 2, 7-16. [CrossRef]

57. Birdi, K. Handbook of Surface and Colloid Chemistry; CRC Press: Boca Raton, FL, USA, 2009; ISBN 978-0-8493-7327-5.

58. Kuo, C.-H.; Lee, C.-L. Treatment of oil/water emulsions using seawater-assisted microwave irradiation. Sep. Purif. Technol. 2010, 74, 288-293. [CrossRef]

59. Canselier, J.P.; Poux, M. Emulsion Preparation: Theoretical Notions and Practical Aspects; PharmaChem: Milano, Italy, $2004 ;$ pp. 16-21.

60. Goodarzi, F.; Zendehboudi, S. A Comprehensive Review on Emulsions and Emulsion Stability in Chemical and Energy Industries. Can. J. Chem. Eng. 2019, 97, 281-309. [CrossRef]

61. Ivanov, I.B.; Danov, K.; Kralchevsky, P.A. Flocculation and coalescence of micron-size emulsion droplets. Colloids Surf. A Physicochem. Eng. Asp. 1999, 152, 161-182. [CrossRef]

62. Tadros, T.F. Emulsion Formation, Stability, and Rheology. In Emulsion Formation and Stability; Wiley: Hoboken, NJ, USA, 2013; pp. 1-75.

63. Ivanov, I.B.; Kralchevsky, P. Stability of emulsions under equilibrium and dynamic conditions. Colloids Surf. A Physicochem. Eng. Asp. 1997, 128, 155-175. [CrossRef]

64. Sainath, K.; Ghosh, P. Stabilization of Silicone Oil-in-Water Emulsions by Ionic Surfactant and Electrolytes: The Role of Adsorption and Electric Charge at the Interface. Ind. Eng. Chem. Res. 2013, 52, 15808-15816. [CrossRef] 
65. Taylor, P. Ostwald ripening in emulsions. Adv. Colloid Interface Sci. 1998, 75, 107-163. [CrossRef]

66. Kokal, S.; Wingrove, M. Emulsion Separation Index: From Laboratory to Field Case Studies. In Proceedings of the SPE Annual Technical Conference and Exhibition, Dallas, TX, USA, 1-4 October 2000; pp. 589-600. [CrossRef]

67. Yeung, A.; Moran, K.; Masliyah, J.; Czarnecki, J. Shear-induced coalescence of emulsified oil drops. J. Colloid Interface Sci. 2003, 265, 439-443. [CrossRef]

68. Jafari, S.M.; Assadpoor, E.; He, Y.; Bhandari, B. Re-coalescence of emulsion droplets during high-energy emulsification. Food Hydrocoll. 2008, 22, 1191-1202. [CrossRef]

69. Paul, B.K.; Moulik, S.P. Microemulsions: An overview. J. Dispers. Sci. Technol. 1997, 18, 301-367. [CrossRef]

70. McClements, D.J. Nanoemulsions versus microemulsions: Terminology, differences, and similarities. Soft Matter 2012, 8, 1719-1729. [CrossRef]

71. Watcharasing, S.; Kongkowit, W.; Chavadej, S. Motor oil removal from water by continuous froth flotation using extended surfactant: Effects of air bubble parameters and surfactant concentration. Sep. Purif. Technol. 2009, 70, 179-189. [CrossRef]

72. Rong, F.; Liu, D.; Hu, Z. Stability of oil-in-water emulsions by SDS compound. Pet. Sci. Technol. 2018, 36, 2157-2162. [CrossRef]

73. Delmas, T.; Piraux, H.; Couffin, A.-C.; Texier, I.; Vinet, F.; Poulin, P.; Cates, M.E.; Bibette, J. How To Prepare and Stabilize Very Small Nanoemulsions. Langmuir 2011, 27, 1683-1692. [CrossRef]

74. Gupta, A.; Eral, H.B.; Hatton, T.A.; Doyle, P.S. Nanoemulsions: Formation, properties and applications. Soft Matter 2016, 12, 2826-2841. [CrossRef] [PubMed]

75. Cox, R.D. Fundamental emulsion science (Part 1). Househ. Pers. Care 2012, 7, 28-31.

76. Cox, R.D. Fundamental emulsion science (Part 2). Househ. Pers. Care 2012, 7, 18-20.

77. Mohammed, T.; Abbas, E.; Ahmed, T. Turbidity and oil removal from oilfield produced water, middle oil company by electrocoagulation technique. MATEC Web Conf. 2018, 162, 05010. [CrossRef]

78. Ichikawa, T. Electrical demulsification of oil-in-water emulsion. Colloids Surf. A Physicochem. Eng. Asp. 2007, 302, 581-586. [CrossRef]

79. Sun, Q. The physical origin of hydrophobic effects. Chem. Phys. Lett. 2017, 672, 21-25. [CrossRef]

80. Zungur, A.; Koç, M.; Kaymak-Ertekin, F. Physical properties of olive oil in water model emulsion: Effect of aqueous and oil phase concentration and homogenization Types. Akad. Gida 2015, 13, 22-34.

81. Pate, K.; Safier, P. Chemical metrology methods for CMP quality. In Advances in Chemical Mechanical Planarization (CMP); Elsevier: Amsterdam, The Netherlands, 2016; pp. 299-325.

82. Derkach, S. Rheology of emulsions. Adv. Colloid Interface Sci. 2009, 151, 1-23. [CrossRef] [PubMed]

83. Deshmukh, O.; Ende, D.V.D.; Stuart, M.C.; Mugele, F.; Duits, M.H. Hard and soft colloids at fluid interfaces: Adsorption, interactions, assembly \& rheology. Adv. Colloid Interface Sci. 2015, 222, 215-227. [CrossRef] [PubMed]

84. Al-Mulla, A.; Gupta, R.K. Droplet coalescence in the shear flow of model emulsions. Rheol. Acta 2000, 39, 20-25. [CrossRef]

85. Mendoza, A.J.; Guzmán, E.; Pedrero, F.M.; Ritacco, H.; Rubio, R.G.; Ortega, F.; Starov, V.M.; Miller, R. Particle laden fluid interfaces: Dynamics and interfacial rheology. Adv. Colloid Interface Sci. 2014, 206, 303-319. [CrossRef]

86. Hu, Y.-T.; Ting, Y.; Hu, J.-Y.; Hsieh, S.-C. Techniques and methods to study functional characteristics of emulsion systems. J. Food Drug Anal. 2017, 25, 16-26. [CrossRef] [PubMed]

87. Wang, B.; Tian, H.; Xiang, D. Stabilizing the Oil-in-Water Emulsions Using the Mixtures of Dendrobium Officinale Polysaccharides and Gum Arabic or Propylene Glycol Alginate. Molecules 2020, 25, 759. [CrossRef] [PubMed]

88. Maindarkar, S.; Dubbelboer, A.; Meuldijk, J.; Hoogland, H.; Henson, M. Prediction of emulsion drop size distributions in colloid mills. Chem. Eng. Sci. 2014, 118, 114-125. [CrossRef]

89. Kokal, S.L. Crude Oil Emulsions: A State-Of-The-Art Review. SPE Prod. Facil. 2005, 20, 5-13. [CrossRef]

90. A Pathak, J. Layered Droplet Microstructures in Sheared Emulsions: Finite-Size Effects. J. Colloid Interface Sci. 2002, 255, 391-402. [CrossRef] [PubMed]

91. Hunter, R. Zeta Potential in Colloid Science: Principles and Applications; Ottewill, R., Rowell, R., Eds.; Academic Press: London, UK, 1981; ISBN 0-12-361960-2.

92. Biriukov, D.; Fibich, P.; Predota, M. Zeta Potential Determination from Molecular Simulations. J. Phys. Chem. C 2020 124, 3159-3170. [CrossRef]

93. Jesionowski, T. Influence of aminosilane surface modification and dyes adsorption on zeta potential of spherical silica particles formed in emulsion system. Colloids Surf. A Physicochem. Eng. Asp. 2003, 222, 87-94. [CrossRef]

94. Jesionowski, T.; Nowacka, M.; Ciesielczyk, F. Electrokinetic properties of hybrid pigments obtained via adsorption of organic dyes on the silica support. Pigment. Resin Technol. 2012, 41, 9-19. [CrossRef]

95. Watanabe, Y. Flocculation and me. Water Res. 2017, 114, 88-103. [CrossRef] [PubMed]

96. Jarvis, P.; Sharp, E.; Pidou, M.; Molinder, R.; Parsons, S.A.; Jefferson, B. Comparison of coagulation performance and floc properties using a novel zirconium coagulant against traditional ferric and alum coagulants. Water Res. 2012, 46, $4179-4187$. [CrossRef] [PubMed]

97. Grasso, D.; Subramaniam, K.; Butkus, M.; Strevett, K.; Bergendahl, J. A review of non-DLVO interactions in environmental colloidal systems. Rev. Environ. Sci. Biotechnol. 2002, 1, 17-38. [CrossRef]

98. Lin, F.; Suda, J.; Yeung, A. A small point regarding DLVO coagulation conditions. J. Colloid Interface Sci. 2014, 430, 113-115. [CrossRef] [PubMed] 
99. López-Esparza, R.; Altamirano, M.A.B.; Pérez, E.; Goicochea, A.G. Importance of Molecular Interactions in Colloidal Dispersions. Adv. Condens. Matter Phys. 2015, 2015, 683716. [CrossRef]

100. Dagastine, R.R.; Chau, T.T.; Chan, D.; Stevens, G.W.; Grieser, F. Interaction forces between oil-water particle interfaces-NonDLVO forces. Faraday Discuss. 2004, 129, 111-124. [CrossRef]

101. Rabinovich, Y.; Baran, A. The role of structural forces in the stability of oil-in-water emulsions. Colloids Surf. 1991, 59, 47-57. [CrossRef]

102. Balaj, R.V.; Zarzar, L.D. Reconfigurable complex emulsions: Design, properties, and applications. Chem. Phys. Rev. 2020, 1, 011301. [CrossRef]

103. Trefalt, G.; Borkovec, M. Overview of DLVO Theory. 2014, pp. 1-10. Available online: https://archive-ouverte.unige.ch/unige: 148595 (accessed on 19 April 2021).

104. Ohshima, H. The Derjaguin-Landau-Verwey-Overbeek (DLVO) Theory of Colloid Stability. Electr. Phenom. Interfaces Biointerfaces 2012, 27-34. [CrossRef]

105. Smith, A.M.; Borkovec, M.; Trefalt, G. Forces between solid surfaces in aqueous electrolyte solutions. Adv. Colloid Interface Sci. 2020, 275, 102078. [CrossRef] [PubMed]

106. Marina, P.F.; Cheng, C.; Sedev, R.; Stocco, A.; Binks, B.P.; Wang, D.; Facal, P. Van der Waals Emulsions: Emulsions Stabilized by Surface-Inactive, Hydrophilic Particles via van der Waals Attraction. Angew. Chem. Int. Ed. 2018, 57, 9510-9514. [CrossRef] [PubMed]

107. Liang, Y.; Hilal, N.; Langston, P.; Starov, V. Interaction forces between colloidal particles in liquid: Theory and experiment. Adv. Colloid Interface Sci. 2007, 134-135, 151-166. [CrossRef] [PubMed]

108. Faraudo, J.; Andreu, J.S.; Camacho, J. Understanding diluted dispersions of superparamagnetic particles under strong magnetic fields: A review of concepts, theory and simulations. Soft Matter 2013, 9, 6654-6664. [CrossRef]

109. Bishop, K.J.M.; Wilmer, C.; Soh, S.; Grzybowski, B.A. Nanoscale Forces and Their Uses in Self-Assembly. Small 2009, 5, 1600-1630. [CrossRef]

110. Wall, S. The history of electrokinetic phenomena. Curr. Opin. Colloid Interface Sci. 2010, 15, 119-124. [CrossRef]

111. Ghernaout, D.; Naceur, M. A review of electrocoagulation as a promising coagulation process for improved organic and inorganic matters removal by electrophoresis and electroflotation. Desalination Water Treat. 2011, 28, 287-320. [CrossRef]

112. Tcholakova, S.; Denkov, N.; Ivanov, I.B.; Campbell, B. Coalescence stability of emulsions containing globular milk proteins. Adv. Colloid Interface Sci. 2006, 123-126, 259-293. [CrossRef]

113. Marriaga-Cabrales, N.; Machuca-Martínez, F. Fundamentals of electrocoagulation. In Evaluation of Electrochemical Reactors as a New Way to Environmental Protection; Peralta-Hernández, J.M., Rodrigo-Rodrigo, M.A., Martínez-Huitle, C.A., Eds.; Research Signpost: Kerala, India, 2014; pp. 1-16, ISBN 978-81-308-0549-8.

114. Ghernaout, D.; Al-Ghonamy, A.I.; Naceur, M.W.; Boucherit, A.; Messaoudene, N.A.; Aichouni, M.; Mahjoubi, A.A.; Elboughdiri, N.A. Controlling Coagulation Process: From Zeta Potential to Streaming Potential. Am. J. Environ. Prot. 2015, 4, 16. [CrossRef]

115. Ninham, B. On progress in forces since the DLVO theory. Adv. Colloid Interface Sci. 1999, 83, 1-17. [CrossRef]

116. Eom, N.; Parsons, D.F.; Craig, V.S.J. Roughness in Surface Force Measurements: Extension of DLVO Theory To Describe the Forces between Hafnia Surfaces. J. Phys. Chem. B 2017, 121, 6442-6453. [CrossRef] [PubMed]

117. Marenduzzo, D.; Finan, K.; Cook, P.R. The depletion attraction: An underappreciated force driving cellular organization. J. Cell Biol. 2006, 175, 681-686. [CrossRef] [PubMed]

118. Sun, Q.; Zhang, M.; Cui, S. The structural origin of hydration repulsive force. Chem. Phys. Lett. 2019, 714, 30-36. [CrossRef]

119. Choi, J.; Kim, G.; Choi, S.; Kim, K.; Han, Y.; Bradford, S.A.; Choi, S.Q.; Kim, H. Application of Depletion Attraction in Mineral Flotation: I. Theory. Minerals 2018, 8, 451. [CrossRef]

120. Yong, J.; Chen, F.; Yang, Q.; Bian, H.; Du, G.; Shan, C.; Huo, J.; Fang, Y.; Hou, X. Oil-Water Separation: A Gift from the Desert. Adv. Mater. Interfaces 2016, 3, 1-7. [CrossRef]

121. Kwon, G.; Kota, A.K.; Li, Y.; Sohani, A.; Mabry, J.M.; Tuteja, A. On-Demand Separation of Oil-Water Mixtures. Adv. Mater. 2012, 24, 3666-3671. [CrossRef]

122. Smathers, C.J.; Jackson, T.; Buckwald, S.; Gonzalo, R.; McPherson, R. Technology Update: New Adsorption Media Technology Meets Water-Treatment Challenges. J. Pet. Technol. 2018, 70, 18-20. [CrossRef]

123. Bal, V. Coagulation behavior of spherical particles embedded in laminar shear flow in presence of DLVO-and non-DLVO forces. $J$. Colloid Interface Sci. 2020, 564, 170-181. [CrossRef] [PubMed]

124. Ghernaout, D.; Ghernaout, B. Sweep flocculation as a second form of charge neutralisation-A review. Desalination Water Treat. 2012, 44, 15-28. [CrossRef]

125. Jiang, J.-Q. The role of coagulation in water treatment. Curr. Opin. Chem. Eng. 2015, 8, 36-44. [CrossRef]

126. Lee, K.E.; Morad, N.; Teng, T.T.; Poh, B.T. Development, characterization and the application of hybrid materials in coagulation/flocculation of wastewater: A review. Chem. Eng. J. 2012, 203, 370-386. [CrossRef]

127. Polasek, P. Technical note: Significance and determination of fraction of non-separable particles of impurities in water purification. Water $S A$ 2014, 40, 89. [CrossRef]

128. Sahu, O.; Chaudhari, P. Review on Chemical treatment of Industrial Waste Water. J. Appl. Sci. Environ. Manag. 2013, 17, 241-257. [CrossRef]

129. Chemical Coagulation Efficiency in Removal of Water Turbidity. Int. J. Pharm. Res. 2018, 10, 188-194. [CrossRef] 
130. Prabhakaran, G.; Manikandan, M.; Boopathi, M. Treatment of textile effluents by using natural coagulants. Mater. Today Proc. 2020, 33, 3000-3004. [CrossRef]

131. Kulkarni, S.J. An Insight into Paint and Textile Effluent Treatment. Int. J. Sci. Res. Chem. (IJSRCH) 2017, 2, 9-12.

132. Wang, C.; Alpatova, A.; McPhedran, K.; El-Din, M.G. Coagulation/flocculation process with polyaluminum chloride for the remediation of oil sands process-affected water: Performance and mechanism study. J. Environ. Manag. 2015, 160, 254-262. [CrossRef] [PubMed]

133. Kulkarni, S.J.; Goswami, A.K. A Review on Wastewater Treatment for Petroleum Industries and Refineries. Int. J. Innov. Res. Sci. Eng. Technol. 2015, 1, 280-283.

134. Sillanpää, M.; Ncibi, M.C.; Matilainen, A.; Vepsalainen, M. Removal of natural organic matter in drinking water treatment by coagulation: A comprehensive review. Chemosphere 2018, 190, 54-71. [CrossRef]

135. Harif, T.; Khai, M.; Adin, A. Electrocoagulation versus chemical coagulation: Coagulation/flocculation mechanisms and resulting floc characteristics. Water Res. 2012, 46, 3177-3188. [CrossRef]

136. Yuksel, E.; Gurbulak, E.; Eyvaz, M. Decolorization of a reactive dye solution and treatment of a textile wastewater by electrocoagulation and chemical coagulation: Techno-economic comparison. Environ. Prog. Sustain. Energy 2012, 31, 524-535. [CrossRef]

137. Zhao, Y.; Gao, B.; Zhang, G.; Phuntsho, S.; Wang, Y.; Yue, Q.; Li, Q.; Shon, H. Comparative study of floc characteristics with titanium tetrachloride against conventional coagulants: Effect of coagulant dose, solution $\mathrm{pH}$, shear force and break-up period. Chem. Eng. J. 2013, 233, 70-79. [CrossRef]

138. Yeap, K.L.; Teng, T.T.; Poh, B.T.; Morad, N.; Lee, K.E. Preparation and characterization of coagulation/flocculation behavior of a novel inorganic-organic hybrid polymer for reactive and disperse dyes removal. Chem. Eng. J. 2014, 243, 305-314. [CrossRef]

139. Ukiwe, L.N.; Alinnor, J.I. Assessment of Polyacrylamide and Aluminum Sulphate Coagulants in Turbidity Removal in Wastewater. Terr. Aquat. Environ. Toxicol. 2012, 6, 132-135.

140. Spicer, P.T.; Sotiris, E.F. Coagulation and Fragmentation: Universal Steady-State Particle-Size Distribution. AIChE J. 1996, 42, 1612-1620. [CrossRef]

141. Greville, A.S.; Environmental, E.T. How to Select a Chemical Coagulant and Flocculant. In Proceedings of the Alberta Water \& Wastewater Operators Association 22th Annual Seminar, 11-14 March 1997; pp. 1-24. Available online: https: / / sswm.info/sites/default/ files/reference_attachments/GREVILLE\%201997\%20\%20How\%20to\%20Select\%20a\%20 Chemical\%20Coagulant\%20and\%20Flocculant.pdf (accessed on 20 March 2021).

142. Lee, C.S.; Robinson, J.; Chong, M.F. A review on application of flocculants in wastewater treatment. Process. Saf. Environ. Prot. 2014, 92, 489-508. [CrossRef]

143. Teh, C.Y.; Budiman, P.M.; Shak, K.P.Y.; Wu, T.Y. Recent Advancement of Coagulation-Flocculation and Its Application in Wastewater Treatment. Ind. Eng. Chem. Res. 2016, 55, 4363-4389. [CrossRef]

144. Yavuz, C.; Vaizoglu, S.; Guler, C. Aluminium in Drinking Water. TAF Prev. Med. Bull. 2013, 12, 589-596. [CrossRef]

145. Butler, E.; Hung, Y.-T.; Yeh, R.Y.-L.; Al Ahmad, M.S. Electrocoagulation in Wastewater Treatment. Water 2011, 3, 495-525. [CrossRef]

146. Ghernaout, D.; Elboughdiri, N. Electrochemical Technology for Wastewater Treatment: Dares and Trends. OALib 2020, 7, 1-17. [CrossRef]

147. Moussa, D.T.; El-Naas, M.H.; Nasser, M.; Al-Marri, M.J. A comprehensive review of electrocoagulation for water treatment: Potentials and challenges. J. Environ. Manag. 2017, 186, 24-41. [CrossRef]

148. Fukushima, J.; Tatsuta, H.; Ishii, N.; Chen, J.; Nishiumi, T.; Aoki, K. Possibility of coalescence of water droplets in W/O emulsions by means of surface processes. Colloids Surfaces A Physicochem. Eng. Asp. 2009, 333, 53-58. [CrossRef]

149. Shim, H.Y.; Lee, K.S.; Lee, D.S.; Jeon, D.S.; Park, M.S.; Shin, J.S.; Lee, Y.K.; Goo, J.W.; Kim, S.B.; Chung, D.Y. Application of Electrocoagulation and Electrolysis on the Precipitation of Heavy Metals and Particulate Solids in Washwater from the Soil Washing. J. Agric. Chem. Environ. 2014, 3, 130-138. [CrossRef]

150. Eow, J. Electrostatic enhancement of coalescence of water droplets in oil: A review of the technology. Chem. Eng. J. 2002, 85, 357-368. [CrossRef]

151. Mhatre, S.; Vivacqua, V.; Ghadiri, M.; Abdullah, A.; Al-Marri, M.J.; Hassanpour, A.; Hewakandamby, B.; Azzopardi, B.; Kermani, B. Electrostatic phase separation: A review. Chem. Eng. Res. Des. 2015, 96, 177-195. [CrossRef]

152. Eow, J.S.; Ghadiri, M.; Sharif, A.O.; Williams, T.J. Electrostatic enhancement of coalescence of water droplets in oil: A review of the current understanding. Chem. Eng. J. 2001, 84, 173-192. [CrossRef]

153. Bałdyga, J.; Tyl, G.; Bouaifi, M. Perikinetic and orthokinetic aggregation of small solid particles in the presence of strong repulsive forces. Chem. Eng. Res. Des. 2018, 136, 491-501. [CrossRef]

154. Rubio, J.; Souza, M.L.; Smith, R.W. Overview of flotation as a wastewater treatment technique. Miner. Eng. 2002, 15, 139-155. [CrossRef]

155. Hogg, R. Bridging Flocculation by Polymers. KONA Powder Part. J. 2013, 30, 3-14. [CrossRef]

156. Ives, K. Coagulation and Flocculation Part II-Orthokinetic Flocculation. In Solid-Liquid Separation; Elsevier: Amsterdam, The Netherlands, 1990; pp. 98-131.

157. Chen, L.; Serad, G.; Carbonell, R. Effect of mixing conditions on flocculation kinetics of wastewaters containing proteins and other biological compounds using fibrous materials and polyelectrolytes. Braz. J. Chem. Eng. 1998, 15, 358-368. [CrossRef]

158. Kroupa, M.; Vonka, M.; Soos, M.; Kosek, J. Size and Structure of Clusters Formed by Shear Induced Coagulation: Modeling by Discrete Element Method. Langmuir 2015, 31, 7727-7737. [CrossRef] 
159. Ghernaout, D.; Al-Ghonamy, A.I.; Boucherit, A.; Ghernaout, B.; Naceur, M.W.; Messaoudene, N.A.; Aichouni, M.; Mahjoubi, A.A.; Elboughdiri, N.A. Brownian Motion and Coagulation Process. Am. J. Environ. Prot. 2015, 4, 1. [CrossRef]

160. Jarvis, P.; Jefferson, B.; Parsons, S.A. Measuring Floc Structural Characteristics. Rev. Environ. Sci. Bio/Technol. 2005, 4, 1-18. [CrossRef]

161. Yu, W.; Gregory, J.; Campos, L.C.; Graham, N. Dependence of floc properties on coagulant type, dosing mode and nature of particles. Water Res. 2015, 68, 119-126. [CrossRef] [PubMed]

162. Tzoupanos, N.D.; Zouboulis, I. Coagulation-Flocculation Processes in Water/Wastewater Treatment: The Application of New Generation of Chemical Reagents. In Proceedings of the 6th IASME/WSEAS International Conference on Heat Transfer, Thermal Engineering and Environment, Rhodes, Greece, 20-22 August 2008; pp. 309-317. Available online: http://www.wseas.us/elibrary/conferences/2008/rhodes/hte/hte47.pdf (accessed on 14 June 2021).

163. Borchate, S.S.; Kulkarni, G.S.; Kore, S.V.; Kore, V.S. Application of coagulation flocculation for vegetable tannery wastewater. Int. J. Eng. Sci. Technol. 2012, 4, 1944-1948. 